
geotechnical investigations for Highways in karst and flysch terrains" financed by Ministry of Sciennce and Technology of the Republic of Croatia

\title{
PROPOSAL FOR METHODOLOGY TO BE APPLIED TO ROAD CONSTRUCTION IN THE KARSTIFIED CARBONATE AND CLASTIC (FLYSCH) TERRAINS IN SOUTHERN CROATIA
}

\author{
Slobodan ŠESTANOVIĆ ${ }^{1}$, Cesare RODA ${ }^{2}$ and Miro ANDRIĆ ${ }^{3}$ \\ ${ }^{1}$ Civil Engineering Faculty, University of Split, Matice hrvatske 15, HR-21000 Split, Croatia \\ ${ }^{2}$ Dipartimento di Georisorse e Territorio, Universitá di Udine, Via Cotonificio 114, \\ 33100 Udine, Italia \\ ${ }^{3}$ Geofizika, Savska cesta 66, HR-10000 Zagreb, Croatia
}

Key-words: Methodology, Investigation works, Roads, Karst, Flysch, Southern Croatia

The suggested methodology includes an approach to investigations which has the objective of obtaining all relevant data on the environment through which the road corridor is planned. This implies an integrated approach to the programming and the implementation of investigation works which, however, cannot be applied to all cases. Frequent changes which are encountered over small distances in the karst and flysch terrains can be studied simultaneously since these layers are generally in contact in the coastal regions in Croatia. The paper presents an efficient methodology applied to investigation works planned according to types of structures and phases of the road planning. The preliminary design phase should include all planned investigation works in order to solve the number of problems relevant to the final design phase and to the conditions and possibilities of road construction. The paper also stresses the necessity of precisely defining the lithostratigraphical and tectonic features as a prerequisite for planning the scope and quantity of investigation works and for proper interpretation of all engineering-geological and hydrogeological relations.

\section{Introduction}

The realization of a plan for road construction is usually preceded by investigation which represent a basis for satisfactory development of the feasibility study followed by investigations related to the preliminary and final designs. The types and methods of investigations therefore depend upon the design phase and particularly upon the configuration of the terrain through which the road passes. Coastal regions of Southern Croatia and its hinterland consist mainly of karstified limestone terrains and clastic flysch layers. Extensive investigation which had been previously carried out made it possible to study these terrains using a great number of relevant data. Althought karst and flysch terrains differ in origin, petro-physical characteristics and resistance to exodynamic factors, they share the occurrence of frequent changes within small areas. This fact makes it necessary to adopt an integrated and comprehensive approach to investigation works, particularly for the construction of roads since they often cover distances of more than $100 \mathrm{~km}$. Consequently, satisfactory pavement design and the planning of excavations in the rock mass make it necessary to obtain all relevant data on the rock
Ključne riječi: Metodologija, Istraživački radovi, Cestovne prometnice, Krš, Fliš, Južna Hrvatska

Predložena metodologija sadrži pristup istraživanjima koja teže postizanju svih relevantnih spoznaja o prirodnom okolišu u kojem se neka prometnica planira izvesti. To osigurava osnovu za jedinstveni pristup programiranju i izvođenju istraživačkih radova, ali bez pretenzija na univerzalnost. Prikazan je način funkcionalnog povezivanja istraživačkih radova u zavisnosti o objektima i fazi projektiranja prometnice. Predviđeno je da se u fazi istraživanja za idejni projekt obave svi programirani istraživački radovi u cijelosti, kako bi se odgovorilo na što veći broj pitanja nužnih za cjelovitost izradbe izvedbenog projekta, ali i o uvjetima i mogućnostima izvedbe prometnice. Naglašena je prvenstvena potreba cjelovitog definiranja litostratigrafskih i tektonskih odnosa kao temeljnog preduvjeta za inženjerskogeološka i hidrogeološka istraživanja u procesu projektiranja i izgradnje cesta u okršenim vapnenačkim i klastičnim (flišnim) terenima južne Hrvatske.

properties and the surrounding terrain. The methodology for planning investigation works in phases for the design, construction and maintenance of roads in karst and flysch terrains in the Republic of Croatia has not yet been developed. Therefore, frequently various sections of the same road were frequently treaed differently since they were studied by teams of researchers/engineers with different approaches to the problem. This made the construction of the road and its subsequent maintenance more difficult and time consuming.

The objective of this paper is to present a possible methodology to be applied to investigation works in karst and flysch terrains in order to achieve satisfactory results. The staring assumption is that the origin of rocks in the karstified and flysch terrains and the effects exerted by current endodynamic and exodynamic factors are of primary importance for understanding both the present state and the future conditions which will be a result of the road construction. The proposal for this methodology was influenced by the published papers by the following autors: Mc Lean \& Gribble (1979); Fookes et al., (1985); I p p o li t o et al., (1991); D a c h ro t h (1992). 


\section{Methodology}

Types of investigation works used in road construction

In order to determine successively and precisely the characteristics of the terrain (environment) during road construction, it is necessary to plan all preliminary works so that the results can be applied to all phases of the project: planning, construction and maintenance. Several types of investigations and their results are presented below.

Morphological investigations have the objective of determining the relief formations, their origin and the changes they underwent in the past, and also of predicting the changes which will be caused by the construction of the road and its influence upon the relief. All these changes will significantly affect the design of the route and the accompanying facilities (B r u n s de n et al., 1975; D a c h r o th, 1992) and hence, the total constructions cost. Consequently, it is necessery to mark zones differing in elevation and morphology (F o o k e s et al., 1985), that can be found in great number along the Croatian coastal belt of the Adriatic sea.

Climatic conditions, rainfall, temperature, wind and fog can be limiting factors in road construction processes, particularly in mountainous zones. The climate influences the selection of the route, the dynamics of engineering works and the road maintenance schedule. Climatological factors also affect the degree of rock weathering, i.e, the stability of cut slopes, particularly in periods of intensive rainfall (S t a r k e 1, 1976; F o o k es et al., 1985).

Lithostratigraphical investigations of rocks in karst and flysch terrains will yield results which will influence the design of the road, the tunneling speed and the protection of tunnels und cut slopes in excavations and fills. The stability of the cut slopes will depend upon the types of layers and their degree of weathering, the atmospheric conditions and the presence of groundwater. The lithostratigraphical features will also influence the selection of locations for temporary quarries and the appearance of torrents, slides and slips, i.e. phenomena which can have hazardous effects upon the stability of the road.

Tectonic investigations are very important in the design phase, but also during the road construction and its maintenance, especially with regard to tunnels, cuts and excavations. Such investigations should be given priority since tectonic movements affect the engineering-geological and hydrogeological characteristics of karst and flysch terrains, i.e., those features which directly influence the planning, construction, protection and maintenance of the road and related structures. Remote sensing methods are very suitable in defining these tectonic movements and should be used as often as possible.

Engineering-geological investigations of rocks and terrains are carried out in order to determine the natural endodynamic and exodynamic processes and phenomena, composition, stucture and properties of the layers along the route corridor which makes it possible to predict the possible changes and type of protection required for each specific case. Engineering-geological characteristics of the rocks, either at the surface or immediately below it, are the final product of the influence exerted by various factors; those which affected the rock directly at the place of its origin, and those which changed the characteristics of the rock in the course of time (M c Le a n \& G r i b b l e, 1979; I p p o 1 i t o et al., 1991; D a c h r o th, 1992; Š e s t a n ovi c, 1993). The investigations related to the engineering-geological features of the terrain should include the determination of structural-geological (B a d g 1 e y, 1959; B r a u n et al., 1992; Š e s t a n o vi ć et al., 1993), petrophysical (S c h o n, 1983; K o b r a n o va, 1989), neo-tectonic (P r e 1 o g o v i ć, 1989) and seismic characteristics (C v i j a n o v i ć, 1983.a and 1983.b). Along whith engineering-geological investigations it is necessary to make some investigations in the domain of the rock mechanics as well, not only in situ (rippability, heterogeneity, anisotropy, tensity), but also on the samples and physical models measured in the laboratory (hardness, moduls of contractility, moduls of elasticity, moduls of deformity, compressive strenght, pulling strength, as well as flexibility and sliding strenght, tenacity). The achieved results of the investigations will be used for making a physical and (or) mathematical model in order to ascertain structural-geological characteristics of the rock in (or on) which the highway will be constructed.

Hydrogeological investigations of the rocks and terrains, particularly within the geological framework (H e r a k, 1957,1975, 1977, 1990. and 1991), include the determination of the groundwater origin, its circulation, depth, regime, water budget, quality of water, particularly presence of the main cations $\left(\mathrm{Ca}^{2+}, \mathrm{Mg}^{2+}, \mathrm{Na}^{+}\right.$, and $\left.\mathrm{K}^{+}\right)$and anions $\left(\mathrm{HCO}_{3}^{-}\right.$, $\mathrm{SO}_{42,}$, and $\mathrm{Cl}^{-}$) as there may be brought some erosion and corrosion effects upon the rocks; all these factors are important in predicting the changes which will occur during the road construction and its maintenance (I p p o l i t o et al., 1991; D a c h r o t h, 1992). In karst terrains special attention should be paid to the protection of groundwater from pollutants from the road (M a r g e t a et al., 1985; Ś es t a n ovi ć, 1985 and 1986).

Geophysical investigations have two main objectives: first, to provide help in engineering 
geological map-work in covered terrains and in the assessment of the groundwater level for hydrogeological purposes; and second, to determine various of the relevant physical parameters for the successful design of structures (tunnels, cuts, excavations and foundations for viaducts and bridges). Recommended are seismic and geo-electric methods while other geophysical methods (such as magnetic methods and gravity methods) should be used less frequently (Ov or a k, 1970; S vi be n \& And ri ć, 1977; A n d ri ć \& Svi b e n, 1983; Z a g o r a c, 1983). These investigations are predominantly carried out at the surface, but they are also carried out in exploratory boreholes or among them, as well as in natural or man-made (artificial) underground structures.

Test trenches are excavated in terrains with a thin surface layer in order to determine the characteristics of the subgrade soil. These works include exploratory cuts and excavations and exploratory shafts (pits) (M a g d a 1 e n ić, 1983).

Exploratory boreholes with core drillings yield a number of data on the rock characteristics and soil composition. The core samples yield information on the types of layers, their cracking, weathering and contents of groundwater. Exploratory boreholes make it possible to carry out geophysical measurements in order to determine the following factors: physical characteristics of the rocks, groundwater depth, oscillations of water level and direction of flow, permeability and implementation of grouting curtains in the underground; which makes them very prominent among all the investigations carried out on the terrain (M a g d a le n ić, 1983).

Laboratory tests, particularly those used to determine deformability and strength ( $\mathrm{N}$ o v o s e 1 , 1983) are very important for the design phase. These tests can be properly carried out and will yield satisfactory results if all mineralogical-petrographical, physical and rock mechanical features and the influence of atmospheric conditions and chemically aggressive substances upon rocks are precisely defined. Mineralogical-petrographical features are particularly important since they yield data on the mineral compostion, structure and texture of rocks which influence their strength, hardness and stability. Physical features determine the rock as a real medium which makes it possible to draw conclusions on the following characteristics of rocks: discontinuity, anisotropy and state of stress under natural conditions. Such findings are used for predicting the terrain-structure interaction, changes in the terrain caused by road construction and for the development of mathematical and physical models used for solving many relevant problems before the onset of construction (M ag d a le n i ć et al., 1980; R a zovs k i j et al., 1987). Rock mechanical features (tensile strength, compressive and bending strength, toughness, abrasion strength, elasticity, workability and hardness) also contribute to the definition of rock mass characteristics and make it possible to ensure optimal organization of the works: sheduling, planning selection of equipment, machines and explosives, etc. The data on the influence exerted by atmospheric condition and chemically aggressive substances upon the rock will make it possible to ensure proper protection along the sections where necessary.

Geodetic surveys, although mentioned last, there are of great importance from the geological standpoint since they make it possible to precisely locate faults, large fissures (cracks), karst morphological phenomena, changes in the composition of flysch layers, and as well as the support to all other investigations. These surveys (carried out within geological investigations) are carried out during all phases of the road design, construction and exploitation, but mainly in the preliminary design phase and during road construction. By precisely locating any geological phenomenon it is possible to successfully solve the problems and, thus, to increase the speed of engineering works.

All the presented types of investigation works represent the basis of the methodology used and are functionally connected following a logical sequence. Understandably, the plan of investigations and conclusions related to the results, i.e. the influence upon the terrain and the road, should be developed by a team of experts among which there is a leading role of the engineering geologist. Team work is necessary in all phases in order to ensure that the works will be carried out step by step and thoroughly.

The interaction between planing, investigation works and construction phases

Having defined what investigation works should be carried out in order to achieve the integrity of the investigations, it is important to determine their position with regard to the structure type and their quantity, according to the phase of the project development. The investigations have the following objectives:

* the feasibility study should be used to determine the possibilities for alignment along the desired route corridor,

* preliminary design, with the determined position of the alignment and of all the structures with the accompanying facilities,

* final design, with a finally defined alignment, structures and their method of construction.

The structures which require these investigations are, as follows: 
* the alignment (road corridor),

* tunnels,

* viaducts, bridges, subways and overhead crossings,

* cuts and excavations,

* fills,

* culverts, catchpits and other facilities for the treatment of waste water and its drainage from the road.

Accordingly, the type and range of investigation works will depend upon the terrain, the phase of the project development, the construction and exploitation, and the function of the structure.

\section{Investigations works required for the feasibility study}

This phase of investigation works should result in the following objectives:

* comprehensive knowledge of the morphological and climatological factors,

* main data on the lithostratigraphical and tectonic features of the planned road corridor (referring to the geological maps, and available published papers, and visit to the construction site, with special attention focused on structures location) as shown on the maps (1:50000),

* main data on engineering-geological and hydrogeological features, based on data on terrain structure and tectonic movements, particularly for the location of elements of the surface water drainage system,

* degree of seismic sensitivity of the sections (according to available maps and previous investigations).

\section{Investigation works for the preliminary design}

After the alignment and location of all facilities hae been determined, the next phase is site investigation which includes all data that help engineers in the development of both preliminary and final designs. Hence, in addition to the available morphological and climatological features, determined by site exploration in the feasibility study phase, this phase should define:

* comprehensive lithostratigraphical features and tectonic movements by making detailed geological maps in the corridor which should be up 500 meters wide on both sides of its axis, depending on the complexity of the geological features of the terrain and of the structure type found at the particular section while the decision about it is made by team of experts who are planning the investigation works. The results for the entire alignment are presented in maps (1:25000) and the location of the structures on maps 1:1000.

Engineering-geological, hydrogeological and geophysical investigations, test trenches and exploratory boreholes, laboratory tests and geodetic surveys are successfully carried out by following a logical sequence, taking into account the results of lithostratigraphical investigations and tectonic movements in order to define the following factors:

* engineering-geological features of the rocks and terrain: development of engineering-geological maps and cross-sections for the entire alignment (1:25000) and for the respective facilities (scale $1: 10000$ to $1: 1000)$; structural-geological maps of the site (B a d g l e y, 1959; B r a u n et al., 1992; Š e s t a n o v i ć et al,, 1993), particularly tunnels, excavations and cuts and locations for the pile foundations for bridges and viaducts and sites for outfalls (outlet structures) while evaluating the characteristic of the layers, cracks (their origin, position, width, length, type of filling, surface shape and displacements), faults and folds, existence of cracks under the route or at the sites of structures (B o ž i č e v i ć, 1983; $\mathrm{R}$ o j e-B o n a c c i et al., 1993) definition of the neo-tectonic movements (P r e l o g o v i c, 1989); unstable slopes and slides; prediction of the slope stability in cuts and excavations (H o e k \& Bray, 1974; Gaziev \& Re chit s k i, 1979; V u j e c, 1980; Š e s t a n o vi c et al., 1989 and 1994) and their protection, plotting data onto the maps (1:2000 to 1:500); exodynamic processes and events, predicting the changes caused by the road construction; petro-physical characteristic ( $\mathrm{S} \mathrm{c}$ h o n, 1983; K o b r a n o v a, 1989); locations for temporary quarries; classification of the terrain according to the degree of karstification and rock mass quality in accordance with the methods applied in rock mechanics (IS R M, 1978; Mc Lea n \& G rib ble, $1979 ; \mathrm{N}$ o v o s e 1 et al., 1980 ; C r n k ović, 1983; R o m a n a, 1985).

* hydrogeological features of rock: hydrogeological maps and cross-sections for the entire route corridor (1:25000) and for the structures (1:10000 to 1:1000); groundwater levels and their oscillations, direction of groundwater circulation, capacity of springs, chemical composition, main leakage zones, possibility of waste water collection and treatment, drainage channels.

* geophysical investigations should be carried out particularly along those route sections where the structures will be located. First, the methods for field measurements are applied and the data used as a basis for planning trenches and exploratory boreholes. Geo-electric profiling with various electrode distribution is successfully applied in order to determine weak fault zones, while the seismic-refraction method is applied to determine the degree of karstification and intensity of fractures in depth. By measuring $\mathrm{S}$ waves velocities in addition to $P$ waves velocities it is possible to obtain information on the average dynamic elastic features of the material. Dynamic constants of elasticity are computed: Poisson coefficient, Young s modulus, shear modulus and 
incompressibility modulus are translated using the known correlation relations into the static values necessary for the design process (A l e k s o v s k i \& Mirakovski,1988). The contact between the karstified carbonate rocks and flysch layers is determined by using the geo-electric grouting and seismic shallow reflection methods. In addition, the seismic shallow reflection method makes it possible to locate, in the depth profile, the tectonic zones and caves as well as cavern systems (M a s u d a, 1975; I m a i, 1975; A r a n đe l ović, 1976). Geophysical investigations are also used in order to plan a minimum number of exploratory boreholes and yet achieve optimal results. This economical aspect has to be considered since exploratory boring is the most expensive investigation phase.

* test trenches should always precede exploration boreholes, since they less expensive and can be excavated easily and quickly. They make it possible to determine in situ the thickness of the wearing surface and the integrity of the rock in covered terrains. These investigations can also include exploratory shafts (pits) on the sites for the foundations of piles in viaducts and bridges, exploratory shafts for determining the quality of layers in the tunnel layout (gabarit-outline, overall dimensions).

* exploratory boreholes should be drilled at the site of tunnels, cuts and excavations and also for the foundations for the piles on viaducts and bridges, particularly if certain anomalous zones have been discovered by geophysical investigations (in karstified terrains caves and caverns). Exploratory boreholes (number and layout) should be generally planned according to data obtained by all previous investigations depending on the complexity of the terrain and the planned structure which will be carried out.

Investigation works for the final design

Detailed investigations in the preliminary design, feasibility study and final design phases, according to this methodology, make it possible to carry out additional investigations, if necessary, only on the site of the structures. Such additional investigations may be required during the construction of tunnels in order to determine, as precisely as possible, the engineering-geologic planned profile of the tunel. Furthermore, additional data can be obtained by geophysical explorations in the borehole using "down hole" and "cross hole" methods, and by seismic tomography and well logging in order to determine the weakened zones in the tunnel transect. Additional geophysical investigations can also be necessary at locations where there are steep cuts and deep excavations, piles for bridges and viaducts and especially at sites of facilities for the collection and treatment of waste water from the road. The objective of all these additional investigations is to accurately define the rock mass in the terrain as an actual medium.

Investigations carried out during road construction and its maintenance

\section{Investigations carried out during road construction}

During road construction the investigation works are carried out mainly on the structures in order to test the results and to modify the design should a problem arise during construction.

During the tunneling process continual engineering-geologic recording of the real state of the rock mass is carried out including the facing, sides and arches after each blasting (B a r č o $t \&$ B o j a n i ć, 1993) and classification according to RMR system (B i e n i a w s k i, 1973) and Q system (B a r t o n et al., 1974) and the stability control of underground excavations. The results are presented in drawings (scale: 1:50 to 1:100), and the final actual profile along the tunnel axis and the completed engineering-geological profile are presented at a scale $1: 1000$ to $1: 10000$. These data are particularly important when comparing the planned and actual states in order to verify the categories of the rock mass and excess blasting, which represents the only reliable documentacion in the final financial statement.

Hydrogeological investigations are used to determine the sites of water inflow, its quantity and the humid zones, which is necessary for determining the dimensions of drainage channels and for planning protective activities.

Geophysical investigations are used in this phase to determine the composition and physical properties of materials in the tunnel. A very suitable method employed is "petite seismic", seismic profiling with small bases. Other measurements include the velocities of elastic waves in shallow boreholes dug for that purpose at the side and arch of the tunnel. Detailed data can be obtained by using the micro-geo-electric profiling methods.

\section{Post-construction stage}

When road construction is completed, before it is open for traffic, it is necessary to carry out zero observations of all relevant bench marks on the structures, to records interesting details, and to compare the original plans with the completed state considering the entire road and its accompanying structures. During this stage, quality control is necessary once a month during the first year, and later at least twice a year. These investigations include:

* the influence of current geological exodynamic processes and events, particularly in the areas which were affected by road construction,

* possible settlement of piles under bridges and viaducts, 
* condition of the lining in the tunnel and possible displacements,

* condition of outlets (drainage channels) and other facilities for water drainage,

$*$ possible settlement of the fills.

\section{Discussion and conclusions}

The absence of a consistent methodology which can be applied to roads in the limestone (karst) and clastic (flysch) terrains in Southern Croatia has resulted in the investigation stages and investigation works which, to a certain extent, differ depending upon the complex composition of the terrain and the experience of the planners. Insufficient investigations during the design phase made extensive additional investigations necessary during the construction stage which increased the cost of the road and slowed down the engineering works. Another negative factor was the fact that the investors were reluctant to approve comprehensive investigations during the planing and construction stages because they considered them to be expensive; consequently, the planners were hindered in implementing their ideas and programs.

The suggested methodology, based on the experience of local and foreign researchers, should represent a basis for an integrated approach to programming and implementation of feasibility studies in road construction. This methodology cannot, be applied to all cases; it can be a basis for the verification and assessment of theoretical findings and, subsequently, can be expanded and modified in accordance with new requirements.

The governing principle in the development of this methodology was to connect the types of feasibility studies efficiently with the structures and design stages in order to achieve a gradual and integrated process.
Consequently, we believe that the feasibility study phase should include the solution of the problems of morphology and climatology in a wide route corridor with the main data relevant for the alignment of the road.

The preliminary design stage, which follows after the alignment has been determined, should solve all relevant problems related to road design and its construction. According to the suggested methodology in the preliminary design stage, the conditions and possibilities of implementation should be almost fully (according to the programme) and completely (according to the degree of precision) defined. The role of the geologist, for mapping and tectonic movements, is extremely important in this phase, since without accurate and comprehensive solutions to the problems of lithostratigraphical and tectonic factors the field researcher in engineering geology, hydrogeology and geo-physics will not be able to find efficient solutions. If these conditions are not adopted, the suggested methodology becomes meaningless. The final results of the studies in the preliminary design phase should be anslyzed and coordinated by the project planners and investigators.

In the final design stage it is possible to encounter problems which cannot be solved according to previous studies. Therefore, this stage (if the previous phases had followed the suggested methodology) should include additional studies of specific sites which can be quickly accomplished without slowing down the work in progress.

The construction stage includes engineering-geological supervision. The supervising engineer should use the obtained data to verify that planned works have been realized and may, if necessary, decide on required modifications of the project (field design during construction).

Table1. Review of the interaction between the investigation stages and investigation works with regard to the structures

\begin{tabular}{|c|c|c|c|c|c|c|c|c|c|c|c|c|c|c|c|c|c|c|c|c|c|c|c|c|c|c|c|c|c|c|c|}
\hline \multirow{2}{*}{$\begin{array}{l}\text { Investigation stages } \\
\text { Investigation works }\end{array}$} & \multirow{2}{*}{$\begin{array}{l}\rightarrow \\
\downarrow\end{array}$} & \multicolumn{6}{|c|}{ Feasibility study } & \multicolumn{6}{|c|}{ Preliminary design } & \multicolumn{6}{|c|}{ Final design } & \multicolumn{6}{|c|}{ Construction stage } & \multicolumn{6}{|c|}{$\begin{array}{l}\text { Post-construction } \\
\text { stage and } \\
\text { maintenance }\end{array}$} \\
\hline & & $R A$ & $\pi$ & ve & CE & Fi & os & PA & Tu & ve & $c E$ & $n$ & os & $\mathrm{rA}$ & TU & ve & cE & F & os & rea & $r u$ & ve & CE & A & os & ra & $\pi$ & va & cE & A & os \\
\hline Morphology & & $\bullet$ & $\bullet$ & $\bullet$ & $\bullet$ & $\bullet$ & $\bullet$ & & & & & & & & & & & & & & & & & & & & & & & & \\
\hline Climate & & - & • & $\bullet$ & • & - & - & & & & & & & & & & & & & & & & & & & & & & & & \\
\hline Lithostratigraphy & & H & H & * & H & * & H & $\bullet$ & $\bullet$ & - & $\bullet$ & $\bullet$ & - & & & & & & & & & & & & & & & & & & \\
\hline Tectonics & & H & t & H & H & Hf & H & $\bullet$ & $\bullet$ & - & $\bullet$ & - & $\bullet$ & 3 & (3) & (3) & (3) & & (3) & $\mathscr{H}$ & $\mathscr{H}$ & $\mathscr{H}$ & $\mathscr{H}$ & & $\mathscr{H}$ & & & & & & \\
\hline Engineering Geology & & H & H & H & H & H & H & $\bullet$ & $\bullet$ & $\bullet$ & $\bullet$ & • & $\bullet$ & 3 & (3) & 0 & (3) & (3) & (3) & $\mathscr{H}$ & 28 & $\mathscr{H}$ & म̊ & $\mathscr{2}$ & $\mathscr{H}$ & $¥$ & $¥$ & $¥$ & $¥$ & $¥$ & $¥$ \\
\hline Hydrogeology & & H & H & * & 草 & * & * & $\bullet$ & $\bullet$ & $\bullet$ & $\bullet$ & - & $\bullet$ & (3) & (3) & 0 & (0) & 8 & (3) & $\mathscr{H}$ & 28 & $\mathscr{2}$ & 28 & $\mathscr{2}$ & $\mathscr{H}$ & $\not$ & $¥$ & $¥$ & $¥$ & $¥$ & $¥$ \\
\hline Geophysics & & & & & & & & $\bullet$ & $\bullet$ & - & - & $\bullet$ & $\bullet$ & & (2) & (9) & (3) & & (9) & & $\mathscr{8}$ & $\mathscr{H}$ & H & & $\mathscr{H}$ & & & & & & \\
\hline Exploratory trenches & & & & & & & & $\bullet$ & $\bullet$ & $\bullet$ & $\bullet$ & • & $\bullet$ & & & & & (3) & 0 & & & & & $\mathscr{2}$ & $\mathscr{H}$ & & & & & & \\
\hline Exploratory drilling & & & & & & & & $\bullet$ & $\bullet$ & $\bullet$ & $\bullet$ & - & $\bullet$ & & 0 & & (3) & & $\theta$ & & $\mathscr{H}$ & & $\mathscr{2}$ & & $\mathscr{H}$ & & & & & & \\
\hline Laboratory & & & & & & & & $\cdot$ & $\bullet$ & - & $\bullet$ & - & $\bullet$ & & (c) & & & (c) & () & & $\mathscr{2}$ & $\mathscr{H}$ & $\mathscr{H}$ & $\mathscr{2}$ & $\mathscr{B}$ & & & & & & \\
\hline Geodetic surveys & & 开 & H & H & H & 莫 & H & - & $\bullet$ & - & $\bullet$ & - & - & (2) & (c) & 0 & $\theta$ & 0 & (9) & $\mathscr{2}$ & $\mathscr{H}$ & $\mathscr{2}$ & H & $\mathscr{H}$ & F & 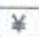 & 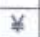 & $¥$ & $¥$ & $¥$ & $\not$ \\
\hline
\end{tabular}

Legend: $\quad R A=$ route alignment;

$T U=$ tunnels:

$\mathrm{VB}=$ viaducts and bridges:

$\mathrm{CE}=$ cuts and excavations;

$\mathrm{FI}=$ fills:

OS = outlet structures and facilities for the collection and drainage of waste water; detailed comprehensive investigations:

first data;

possible additional detailed investigations:

supervision;

occasional investigations. 
The post-construction stage (when the road is in use) requires occasional control (initially more frequent), and the surveyors, after zero recording of the bench marks on the structures, observe the deformations and settlement at certain time intervals (initially more frequent).

The suggested methodology is presentend in Table 1.

Considering the possible and planned intensive construction of roads in Croatia in limestone (karst) and clastic (flysch) terrains after the war, it will be interesting to test the suggested methodology on actual examples and to note its advantages and disadvantages in order to make improvements in the course of time.

\section{Acknowledgment}

We should like to express our gratitude to the Ministry of Science of the Republic of Croatia which financed Research Project "The proposal for the methodology used in the geotechnical investigations for Highways in karst and flysch terrains" which includes this paper.

Received: 6.IV.1995.

Accepted: 20.VT.1995.

\section{RERERENCES}

A leksovski, D. \& Mirakovs ki, G. (1988): Mogućnost korišćenja seizmičkih brzina za određivanje parametara deformabilnosti, otpornosti i čvrstoće stenskih masa. I. jug. simp. o tunelima, 1,7-16, Brijuni.

Andrić, M. \& S vi be n, D. (1983): Primjena seizmoakustičnih metoda. In: Mehanika stijena, temeljenje, podzemni radovi. Edit. I. Jašarevic. DGIT Zagreb and DMSPR Hrvatske, Knj. 1. 95-109, Zagreb.

Ar a n de lovi ć, D. (1976): Geofizika na karstu. Zavod za geološka, hidrološka, geofizička i geotehnička istraživanja, Geofizički institut, posebna izdanja, knjiga 17, pp 220, Beograd.

B a d g le y, C.P. (1959): Structural Methods for the Exploration Geologist. Harper \& Brothers Publ., pp 280, New York.

B a r č o t, D. \& B o j a n i ć, D. (1993): Inženjerskogeološki i geotehnički uvjeti izgradnje tunela Mravinci. Gradevinar Vol.45/No 8, 461-468, Zagreb.

B a r t o n, N., Li e n, R. and L u n d e, J. (1974): Engineering Clasification of Rock Masses for the Design of Tunnel Support. Rock Mechanics, Vol. 6No. 4, 183-286, Wien.

Bieniawski, Z. T. (1989): Engineering Rock Mass Classification: A Complete Manual for Engineers and Geologist in Mining, Civil and Petroleum Engineering. Wiley Interscience Publication, pp 251, New York.

B o ž i č e vi ć, S. (1983): Otkrivanje i proučavanje šupljina pod građevinama u kršu. In: Mehanika stijena, temeljenje, podzemni radovi. Edit. 1. Jašarević. DGIT Zagreb and DMSPR Hrvatske, 247-256, Zagreb.

Braun, K., Š estanović, S., Ba rčot, D. \& Samardžij a 1. (1992): Inženjerskogeološke i strukturološke značajke u funkciji dokazivanja stabilnosti visokih zasjeka u čvrstim stijenama na primjeru dionice poluautoceste MC-11, Solin-klis. Rud.-geolnaft.zb., Vol.4, 59-66, Zagreb.

Brunsden, D., Doornkam p, J. C., Fookes, P. G., Jones, D. K, C. and K e I I y, J. M. H. (1975): Geomorfological Mapping Tecnhniques in Highway Engineering. J. Inst. Highway Eng, 22, 35-41, London.

Crn kovi ć, B. (1983): Postojeće klasifikacije stijenskih masa. In: Mehanika stijena, temeljenje, podzemni radovi. Edit. I. Jašarevic. DGIT Zagreb and DMSPR Hrvatske, Knj. 1, 211-233, Zagreb.

Cvija novič, D. (1983. a): Seizmičnost područja Jugoslavije.
Stručni seminar DIT Zagreb and DPG Hrvatske "Potresno građevinarstvo", 1-12, Zagreb.

Cvi j a n ovi ć, D. (1983. b): Osnove inženjerske seizmologije L. i II. Skripta. GI-FGZ Zagreb, pp 45+28, Zagreb.

D a c h r o t h, W.R. (1992): Baugeologie. 2. Auflage. Springer Lehrbuch, pp 521, Heidelberg.

Fookes, P.G., Swe e n e y, M., M a n by, C.D.N. and M a rt in, R.P. (1985): Geological and Geotehnical Engineering Aspects of Low-Cost Roads in Mountainous Terrain. Eng. Geol. Vol. 21, No. 1/2,1-152, Amsterdam.

G a ziev, E.G. \& Rechits ki, V.I. (1979): Method of Probabilistic Analysis of Rock Slopes Stability. 4th Int. Congr. ISRM, 637-643, Montreaux.

H e r a k, M. (1957): Geološka osnova nekih hidroloških pojava u dinarskom kršu. II. kongr. geol. Jug., 523-535, Sarajevo.

He r a k, M. (1957): Geotektonics and Karst. Acta geoL. 8/21 (Prir. istraž. JAZU 41) 387-395, Zagreb.

Her a k, M. (1977): Tecto-genetic Approach to the Classification of Karst Terrains. Krš Jug, 9/4, 227-238, Zagreb.

H e r a k, M. (1990): Geotectonics, Karst Morfology and Environmental Problems. Environ. Geol. Water Sci, Vol. 15, No 1, 59-60, New York.

H e r a k, M. (1991): Dinaridi. Mobilistički osvrt na genezu i strukturu. Acta geol. 2/21 (Prir. istra. HAZU 63), 35-117, Zagreb.

H o e k, E. \& B r a y, J. (1974): Rock Slope Engineering. Inst. of Mining and Metalurgy, Gresham Press, pp 309, London.

I m a i, T s. (1975): An Introduction to the Geophysical Prospectings for Civil Engineering Purposes. Oyo technical note, TN-11, 1-32, Oyo Corporation, Tokyo.

Ip polito, F, Nicotera, P., Lucin i, P., Civita, M. and de Riso, R. (1991): Geologia tecnica per ingegneri e geologi. ISEDI Petrini edit., IV. ed., V. rist., pp 447, Torino.

I S R M, (1978); Suggested Methods for the Quantitative Description of Discontinuities in Rock masses. ISRM Commision on Standardization of Laboratory and Field Tests. Int. J. Rock Mech. Min.Sci. \& Geomech. Abstr., Vol. 15, No 6, Pergamon Oress, 319-368, London.

Ko br a n ova, V.N. (1989): Petrophysics. Mir Publishers, pp 375, Moscow.

M a g d a l e n i ć, A. (1983): Osnove inženjersko-geoloških istraživanja. In: Mehanika stijena, temeljenje, podzemni radovi. Edit. I. Jašarević. DGIT Zagreb and DMSPR Hrvatske, knj. 1, 3-18, Zagreb.

Magdalenić, A., Crnković, B. i Jašarević, I. (1980): Problemi vezani uz radove u flišu. Zbornik 5. simp. JDMSPR, 2, 93-109, Split-Zagreb.

Marget a, J., Ś estan ovi ć, S. i D or i ć, V. (1985): Izvedba odvodnje magistralne ceste u vodozaštitnom području izvorišta u kršu. Tehnika-Naše gradevinarstvo 39/2, 145-151, Beograd

M a s u d a, H. (1975): Practical Method of Seismic Refraction Analysis for Engineering Study. Oyo Tehnical Note, TN-08, 9-1 -9-6, 10-1 - 10-13, Oyo Corporation, Tokyo.

Mc Lean, A. C. \& G rib ble, C. D. (1979): Geology for Civil Engineers.George Allen \& Unwin, pp 310, Boston - Sydney.

N o v o s e 1, T. (1983): Laboratorijsko ispitivanje čvrstoće i deformabilnosti. In: Mehanika stijena, temeljenje, podzemni radovi. Edit, I. Jašarevic. DGIT Zagreb and DMSPR Hrvatske, knj.1, 235-251, Zagreb.

Novosel, T., Tušar, Z., M ulabdić, M. iKoražija, S. (1980): Ocjena stabilnosti kosina u zasjecima (usjecima) gradenih od karbonatnih stijena. Zbornik 5. simp. JDMSPR, 1, 185- 192, Split-Zagreb.

O vor a k, A. (1970): Seismic and Static Modullus of Rock Masses. II. medunarodni kongres za mehaniku stijena, Referat, Beograd.

Prelog ovic, E. (1989): Neotektonski pokreti u području sjevernog Velebita i dijela Like. Geol. vjesnik 42, 133-147, Zagreb.

Razovskij, L.,ZelinskijI.P.iVaskabojnikov, V.M. (1987): Inženernogeologičeskie prognozi i modeliravanie. Viša škola, pp 208, Kiev - Odesa.

Roje-Bonacci, T., Šestanović, S. and Mišćević, P 
(1993): Geotechnical Problems Encountered in Road Construction in the Karst Areas in Dalmatia (Croatia). Rud. geol.-naft. zb. 5, 79-85, Zagreb.

R o m a n a, M. (1985): New Adjustment Ratings for Application of Bieniawski Clasification to Slopes. Proc. Int. Simp. Rock Mech. Excav. Min. Civ. Works. ISRM, 59-68, Mexico City.

S c h o n, J. (1983): Petrophysik. F. Enke Verlag, pp 405, Stuttgart.

S t a r k e l, L. (1976): The Role of Extreme (Catastrophic) Meteorological Events in Contemporary Evolution of Slopes. In: Derbyshire E. (Edit): Geomorphology and Climate. Wiley, 203-246, New York.

S vi be n, D. \& A n dri C, M. (1977): Primjena geofizičkih metoda za određivanje kvalitete stijena i tla. Nafta, XXVIII, 344-359, Zagreb.

Š e s t a n ov i C, S. (1985): Graditeljski zahvati i zaštita voda u kršu. Naš krš (XI), 18/19, 33-38, Sarajevo.

Š e s t a n ovi ć, S. (1986): Utjecaj građevinskih objekata izvan urbaniziranih područja na vodne resurse u kršu. Acta Cars. $X I V-X V / 1985 / 86,239-244$, Ljubljana.

Š e s t a n ovi 6, S. (1993): Osnove inženjerske geologije - primjena u graditeljstvu. Geing, pp 159, Split.

Šesta nović,S., S a ma rd žij a, I, Č a ga l j, M. i B a r čot, D. (1989): Neki problemi rješavaju stabilnosti kosina u flišnim naslagama. Zbornik VII. simp. JDMSPR, 109-111, Beograd.

Š est a novi ć, S., B r a u n, K. i B a r čo t, D. (1993): Inženjerskogeološke značajke trase prometnice Solin-Klis (Dalmacija - Hrvatska) Rud-geol.-naft. zb. 5, 87-97, Zagreb.

Š est a nović, S., Št a m b u k, N. and S a m a r d ži i a, I. (1994): Control of the Stability and Protection of Cut Slopes in Flysch. Geol. Croatica 47/1, 139-148, Zagreb.

V u j e c, S. (1980): Stabilnost kosina. Zbornik 5 . simp. JDMSPR, 2,41-47, Split-Zagreb.

$\mathrm{Z}$ a g o r a c, Z. (1983): Metode geofizičkih istraživanja. In: Mehanika stijena, temeljenje, podzemni radovi. Edit. I. Jašarević. DGIT Zagreb and DMSPR Hrvatske, knj. 1, 77-93, Zagreb. 